\title{
Decreased Binding of Epidermal Growth Factor in Placentas from Streptozotocin-diabetic Rats
}

Janice F. Sissom, Wendy K. Stenzel, and Joseph B. Warshaw

Department of Pediatrics, The University of Texas Health Science Center at Dallas,

Southwestern Medical School, Dallas, Texas 75235-9063

\begin{abstract}
Placentas from streptozotocin-diabetic rats have previously been shown to be morphologically and biochemically immature when compared with those of control rats. The binding of epidermal growth factor (EGF) to plasma membranes prepared from placentas of control and streptozotocin-diabetic fetuses has been characterized on days 17 and 21 of gestation. Results from competitive binding data analyzed by Scatchard analysis indicate the presence of a single class of receptors on day $17\left(K_{D}=5.4\right.$ $\times 10^{-10}$ ) and the appearance of a second class of binding sites for ${ }^{125}$ I-EGF by day $21\left(K_{D}=3.5 \times 10^{-9}\right)$ in membranes from control fetuses. Placental membranes from diabetic fetuses show decreased specific binding $(\sim 30 \%)$ on both days and the absence of a second class of binding sites on day 21 of gestation. Results from a radioreceptor assay indicate that the quantity of EGF in the serum of fetuses removed from control rats on day 21 is twofold greater than the quantity in serum of fetuses from diabetic rats. These data reveal a developmental increase in EGF-binding sites in the placenta of normal, near-term fetal rats, largely because of the appearance of a second class of binding sites with a lower affinity for EGF. The failure (or delay) of this second class to develop in the diabetic may be important for the control of maturation and growth of this tissue.

\section{Introduction}

In humans, the diabetic state during pregnancy leads to fetal hyperglycemia and hyperinsulinism which results in placentomegaly and fetal macrosomia $(1,2)$. Infants of diabetic mothers also exhibit a delay in lung maturation and a greatly increased risk for the development of hyaline membrane disease (3). In previous studies utilizing fetuses of streptozotocin-diabetic rats $(4,5)$, we reported that hyperglycemia per se was associated with increased placental growth and delayed maturation during late gestation. DNA levels reach a maximum on day 16 in placentas from control rats whereas placentas from diabetic rats continue to increase in DNA content until days 18-19 and are morphologically immature when compared with control tissues. These fetuses; which are hyperglycemic but are not hyperinsulinemic, also exhibit delayed morphologic and biochemical maturation of lung.

This work has been reported in part in abstract form (1985. J. Cell Biol. 101:256a [Abstr. No. 959])

Address reprint requests to Dr. Warshaw. His present address is Department of Pediatrics, Yale University School of Medicine, New Haven, CT 06510-8064. 1987.

Received for publication 17 October 1986 and in revised form 9 March

J. Clin. Invest.

(c) The American Society for Clinical Investigation, Inc.

0021-9738/87/07/0242/06 \$2.00

Volume 80, July 1987, 242-247
To define the mechanisms by which the fetal diabetic state and the concomitant hyperglycemia influence growth and maturation of the placenta, we have investigated the binding of epidermal growth factor (EGF) ${ }^{1}$ to surface receptors of membranes prepared from placentas of control and streptozotocin-diabetic fetuses at different gestational ages. EGF binds to cell surface receptors which are autophosphorylated by a protein kinase on the internal domain of the receptor $(6,7)$. EGF has been shown in many cell types to stimulate an array of biochemical and morphologic changes including cell proliferation, organ differentiation, and transport of small molecules.

Adamson and Warshaw (8) provided evidence that the receptor for EGF could be "down-regulated" in vivo by EGF. Later studies involving the binding characteristics of EGF to placental membranes during stages of gestation indicated that receptor number is increased and binding affinity is decreased as gestation nears term (9). It was suggested that EGF may stimulate proliferation in immature tissues and differentiation as the tissues mature. Lai and Guyda (10) provided data from in vitro experiments that specific binding of EGF to placental membranes increases during gestation to reach a maximum at term. The authors proposed that EGF may be involved in the regulation of fetal growth and development. The data reported here show striking changes in EGF binding to placental membranes of diabetic fetuses and are supportive of the hypothesis that an interaction between glucose supply and receptor binding exists and is important for placental growth and maturation.

\section{Methods}

Animals. Nonpregnant adult virgin female Sprague-Dawley rats (Holtzmann $250-300 \mathrm{~g}$ ) were injected intravenously with $50 \mathrm{mg} / \mathrm{kg}$ of streptozotocin (Upjohn Co., Kalamazoo, MI), a specific pancreatic beta-cell cytotoxin, dissolved in $5 \mathrm{mM}$ citrate buffer, $\mathrm{pH}$ 4.5. Control rats received an equivalent volume of buffer. Serum glucose levels were determined to confirm the diabetic state of each animal, and only those animals with glucose values $>300 \mathrm{mg} \%$ were considered to be diabetic. Females were then placed in cages with stud male rats and tested for the presence of sperm each morning. The morning that sperm were detected was designated day 0 of pregnancy. Approximately $60-70 \%$ of attempted matings were successful.

Preparation of crude cell membrane fraction. Animals were killed by decapitation on days 17 and 21 . The uterine horns were rapidly removed and placed on ice. Placentas were removed, weighed, and processed immediately. All procedures were conducted at $0-4^{\circ} \mathrm{C}$. Plasma membranes were prepared by a modification of the method of Morishige et al. (11). Tissue was homogenized in $10 \mathrm{vol}$ of $0.3 \mathrm{M}$ sucrose in $0.25 \mathrm{M}$ Tris-HCl, $\mathrm{pH} 7.6$, containing $10 \mathrm{mM} \mathrm{MgCl}$ using a Polytron (Brinkmann Instrument Co., Westbury, NY) and the homogenate was centrifuged at 800

1. Abbreviations used in this paper: EGF, epidermal growth factor; TGF, transforming growth factor; TM buffer, Tris- $\mathrm{HCl}$ buffer, $\mathrm{pH} 7.6$, containing $10 \mathrm{mM} \mathrm{MgCl}$. 
$g$ for 10 minutes. The supernatant was centrifuged at $20,000 \mathrm{~g}$ for 20 min and the pellet suspended in $20 \mathrm{vol}$ of $0.25 \mathrm{M}$ Tris- $\mathrm{HCl}$ buffer, $\mathrm{pH}$ 7.6 , containing $10 \mathrm{mM} \mathrm{MgCl}$ (TM buffer). The pellet was twice resuspended in buffer and centrifuged at $20,000 \mathrm{~g}$ for $10 \mathrm{~min}$. The final pellet was resuspended in buffer and adjusted to yield $3 \mathrm{mg}$ of protein $/ \mathrm{ml}$. Protein was assayed according to method of Lowry et al. (12). This fraction was then used in the binding assays.

$5^{\prime}$-Nucleotidase assay. The procedure employed for assay of $5^{\prime}$-nucleotidase is based on measuring the nucleoside produced by the hydrolytic action of the enzyme on the nucleotide substrate. A kit purchased from Sigma Diagnostics (St. Louis, MO) was used to measure the nucleoside employing an enzyme kinetic method reported by Arkesteijn (13). The rate of NAD formation, as determined by the decrease in absorbance at $340 \mathrm{~nm}$, utilizing a Gilford 2600 spectrophotometer (Gilford Instrument Laboratories, Inc., Oberlin, $\mathrm{OH}$ ), is directly proportional to the rate of adenosine formation and therefore, 5 -nucleotidase activity.

${ }^{125}$ I-EGF-binding assay. Membranes from placentas (300 $\mu \mathrm{g}$ of protein per assay tube) were incubated with ${ }^{125}$ I-EGF $(0.06-0.07 \mathrm{ng}$ of EGF containing 30,000-35,000 dpm) in buffer consisting of $0.25 \mathrm{M}$ Tris-HCl, $\mathrm{pH} 7.6,10 \mathrm{mM} \mathrm{MgCl}$, and $0.1 \%$ bovine serum albumin (BSA) at room temperature with continuous shaking. Total assay volume was $0.25 \mathrm{ml}$ and incubation was done in the absence or presence $(3 \mathrm{ng}$ per tube and $1 \mu \mathrm{g}$ per tube) of unlabeled EGF. Samples were removed at time intervals of $15 \mathrm{~min}$ for $90 \mathrm{~min}$ to determine time at which equilibrium was achieved both for the lowest and the highest concentrations of EGF used for Scatchard analysis. EGF binding was then done varying membrane protein concentrations (0-600 $\mu \mathrm{g}$ of protein/assay tube) to determine linearity of binding with respect to protein in the range used for all other experiments ( $300 \mu \mathrm{g}$ of membrane protein per assay tube). Competitive binding was determined by the addition of increasing amounts of unlabeled EGF. EGF (receptor grade) and ${ }^{125}$ I-EGF were purchased from Collaborative Research, Inc. (Lexington, MA). Nonspecific binding was determined by measuring counts bound after addition of an excess ( $1 \mu \mathrm{g}$ per assay tube) of unlabeled EGF. Free ${ }^{125}$ I-EGF was separated from bound EGF by centrifugation in a Beckman microfuge (Beckman Instruments, Inc., Fullerton, CA) at $10,000 \mathrm{~g}$ for $10 \mathrm{~min}$. Tubes were counted for $10 \mathrm{~min}$ in a Packard 5110 gamma counter (Packard Instrument Co., Downers Grove, IL). EGF receptor number and affinity were determined by Scatchard analysis (14) of competitive binding assay data which were evaluated by means of a computer program called LIGAND (15).

Degradation experiment. To determine that EGF degradation did not occur during the time course of binding assays, ${ }^{125}$ I-EGF $\left(2 \times 10^{5}\right.$ $\mathrm{cpm}$ per assay tube) was incubated in the absence (control) and presence (experimental) of placental membrane as described above. Five tubes of each were removed at 15-min time intervals from 0-90 min and immediately centrifuged. The supernatant was removed and protein precipitated by $10 \%$ trichloroacetic acid (TCA) as described by other authors $(1,10)$.

Rebinding experiment. Magnesium chloride $\left(\mathrm{MgCl}_{2}\right)$ was used as a dissociating agent to remove bound EGF from the membranes by a procedure modified from Kelly et al. (16). $\mathrm{MgCl}_{2}$ was dissolved in $\mathrm{TM}$ buffer to give concentrations $1,2,3$, and $4 \mathrm{M}$ and kept at room temperature until use. The binding assay was repeated as described above. After counting, the pellets from the binding assay were resuspended in $0.5 \mathrm{ml}$ of $\mathrm{MgCl}_{2}$, vortexed, and incubated for $5 \mathrm{~min}$. Tubes were centrifuged in a Beckman microfuge at $10,000 \mathrm{~g}$ for $10 \mathrm{~min}$. The supernatant was aspirated and the pellets were counted. The pellets were resuspended in $0.10 \mathrm{ml}$ of binding buffer and binding assay repeated as described above.

Radioreceptor assay. The amount of EGF present in amniotic fluid and fetal serum was measured by radioreceptor assay. Human placental membranes were isolated according to a modification of the method of Hock and Hollenburg (17). All procedures were performed at $0-4^{\circ} \mathrm{C}$. Fresh term human placenta $(150 \mathrm{~g})$ was chopped, rinsed, and homogenized in 10 volumes of $0.250 \mathrm{M}$ sucrose, $0.025 \mathrm{M}$ Tris-HCl, $\mathrm{pH}$ 7.4. The suspension was filtered through cheesecloth and centrifuged for 10 $\min$ at $600 \mathrm{~g}$. The supernatant was centrifuged at $10,000 \mathrm{~g}$ for $30 \mathrm{~min}$, adjusted to contain $0.1 \mathrm{M} \mathrm{NaCl}$ and $0.2 \mathrm{mM} \mathrm{MgSO}_{4}$, and centrifuged for $40 \mathrm{~min}$ at $48,000 \mathrm{~g}$. The pellet was washed with $50 \mathrm{mM}$ Tris- $\mathrm{HCl}$, pH 7.6, centrifuged for $30 \mathrm{~min}$ at $48,000 \mathrm{~g}$, suspended in $15 \mathrm{ml}$ Dulbecco's phosphate-buffered saline (Gibco, Grand Island, NY), $0.1 \mathrm{M}$ Hepes (Sigma Chemical Co.), 0.1\% BSA (Sigma Chemical Co., Fraction V), pH 7.4, to yield a membrane fraction containing $\sim 10-15 \mathrm{mg} / \mathrm{ml}$ protein, and frozen in $100 \mu \mathrm{l}$ aliquots at $-80^{\circ} \mathrm{C}$. Human placental membranes ( $5 \mu \mathrm{g}$ of membrane protein), $40,000-45,000 \mathrm{dpm}^{125} \mathrm{I}-\mathrm{EGF}$, and varying amounts of cold EGF $(0-1,000 \mathrm{ng} /$ tube $)$ or test sample in a final volume of $300 \mu \mathrm{l}$ were incubated in Dulbecco's PBS buffer at room temperature for $1 \mathrm{~h}$ with shaking. The reaction was terminated by the addition of 1 $\mathrm{ml}$ of ice-cold incubation buffer, and filtered through Whatman GF/C filters, (Whatman, Inc., Clifton, NJ) using the Millipore 3025 Sampling Manifold (Millipore Corp., Bedford, MA). The assay tube was rinsed once with $1 \mathrm{ml}$ of ice-cold buffer, and the filter was rinsed three additional times with ice-cold buffer. The filter was counted in a Packard 5110 Gamma scintillation counter. A displacement curve was constructed by plotting bound ${ }^{125}$ I-EGF vs. $\log$ EGF concentration. EGF activity present in the sample was estimated by the amount of ${ }^{125}$ I-EGF displaced.

\section{Results}

As shown in Fig. 1, maximal binding of ${ }^{125}$ I-EGF to placental membranes was achieved in 60-90 min at both the lowest and highest concentration of EGF used to obtain Scatchard plots. Equilibrium was reached by $\mathbf{4 0} \mathrm{min}$ in those samples containing $1 \mu \mathrm{g}$ of EGF per tube (representing nonspecific binding). Under the conditions of the assay, specific binding of ${ }^{125}$ I-EGF was shown to increase linearly with increasing placental membrane protein (Fig. 2). All assays were conducted with $300 \mu \mathrm{g}$ of membrane protein per/tube in a total volume of $250 \mu \mathrm{l}$. There was no statistical difference in percent recovery of 5 -nucleotidase in membrane fractions isolated from control and diabetic placentas. This indicates that the relative purity of membranes was similar in the two groups. Data shown in Fig. 3 represent the results of specific binding of ${ }^{125} \mathrm{I}$-EGF to placental membranes prepared from control and diabetic animals on days 17 and 21 of gestation. Membranes isolated from control rats on day 17 of gestation specifically bound $12.9 \%$ of ${ }^{125} \mathrm{I}-\mathrm{EGF} / \mathrm{mg}$ of protein whereas membranes isolated from diabetic rats bound 7.8\%. Membranes isolated from near term (day 21) control rats specifically bound $16.6 \%$ and those isolated from diabetic rats specifically bound

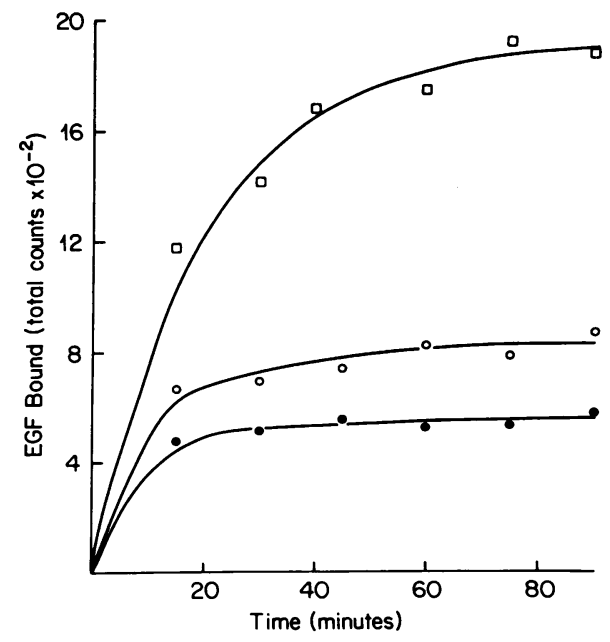

Figure 1. Time course of binding of ${ }^{125} \mathrm{I}-\mathrm{EGF}$ at $22^{\circ} \mathrm{C}$ to placental membranes from rats at 21 days of gestation in the presence of (solid circles) $1,000 \mathrm{ng}$, and (open circles) $3 \mathrm{ng}$, or (open squares) absence of unlabeled EGF. 


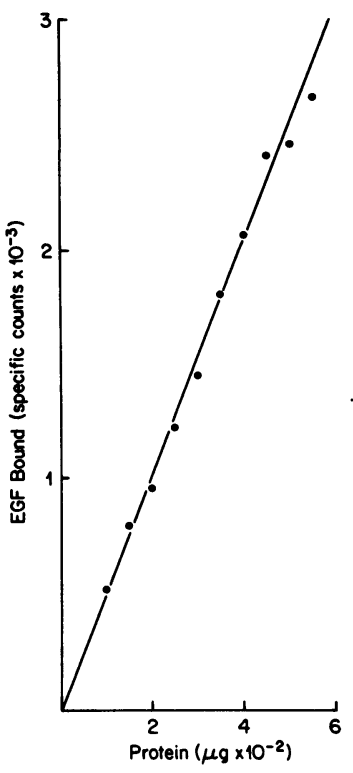

Figure 2. ${ }^{125}$ I-EGF specifically bound as a function of increasing amounts of membrane protein in $100 \mu \mathrm{l}$ of TM buffer. Incubation was done at $22^{\circ} \mathrm{C}$ for $90 \mathrm{~min}$ in a total volume of $250 \mu \mathrm{l}$.

$10.2 \%$. The binding of ${ }^{125} \mathrm{I}$-EGF to membranes prepared from diabetic rats is reduced on each day by $\sim 30 \%$ when compared with binding to membranes prepared from control rats. ${ }^{125} \mathrm{I}$ EGF exposed to placental membranes at $22^{\circ} \mathrm{C}$ was physically intact as assessed by TCA precipitation. There were no statistical differences in control and experimental results at any time during the 90 -min incubation.

To exclude nonspecific effects on binding, a membrane mixing experiment was done utilizing equal amounts of membranes prepared from control and diabetic animals on day 21 of gestation. Specific binding results are shown in Fig. 4. Membranes isolated from placentas of control animals bound $\sim 20.4 \%$ of $\mathrm{EGF} / \mathrm{mg}$ of protein and an equal amount of membrane isolated from placentas of diabetic rats bound $\sim 11.6 \%$. The membranes which were equally mixed bound $\sim 15.6 \% / \mathrm{mg}$ of membrane protein, an amount intermediate to the values obtained from control and diabetic animals.

To determine if results could be influenced by receptor occupancy, for example with EGF or transforming growth factor (TGF)- $\alpha$, we carried out a binding, displacement, and rebinding experiment. Displacement of bound hormone from the receptor

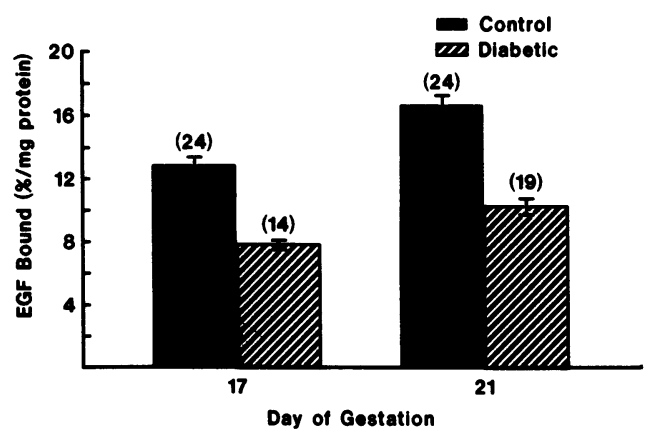

Figure 3. Specific binding of ${ }^{125}$ I-EGF $(0.06-0.07 \mathrm{ng})$ binding to placental membranes from control and diabetic rats on days 17 and 21 of gestation. Data shown are the mean \pm standard error per milligram of membrane protein. The number of determinations is indicated in parentheses. Nonspecific binding was determined in the presence of $1 \mu \mathrm{g}$ of unlabeled EGF per assay tube.

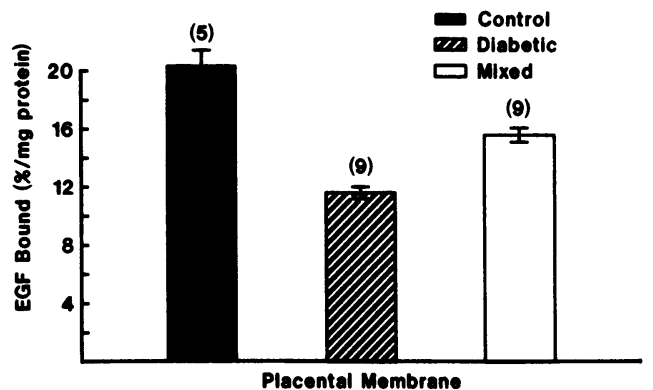

Figure 4. Specific binding of ${ }^{125} \mathrm{I}-\mathrm{EGF}(0.06 \mathrm{ng})$ to placental membranes isolated from control and diabetic rats or to equal amounts of membrane protein from each were incubated with ${ }^{125}$ I-EGF $(30,000$ $\mathrm{dpm})$ in the presence and absence of excess unlabeled EGF ( $1 \mu \mathrm{g}$ per assay tube). Data shown are the mean \pm standard error per milligram of protein. The numbers of determinations is shown in parentheses.

was effectively accomplished using $1 \mathrm{M} \mathrm{MgCl}$. Higher concentrations of $\mathrm{MgCl}_{2}$ resulted in a smaller percentage of rebinding. Specific binding of ${ }^{125} \mathrm{I}-\mathrm{EGF}$ by excess EGF before and after membranes had been treated with $1 \mathrm{M} \mathrm{MgCl}_{2}$ is shown in Fig. 5. Similar to data shown in Fig. 3, membranes from control animals specifically bind $17.6 \%$ of the total ${ }^{125} \mathrm{I}-\mathrm{EGF} / \mathrm{mg}$ of protein whereas membranes from diabetics bind 11.9\%. After displacement with $\mathrm{MgCl}_{2}$, rebinding of ${ }^{125}$ I-EGF was $\sim 80 \%$ of initial values. The ratio of rebinding to initial binding was the same in diabetic and control membranes.

Results from competitive binding data which have been analyzed by Scatchard analysis are shown in Figs. 6 and 7. Fig. 6 represents competitive binding data of ${ }^{125}$ I-EGF to placental membranes isolated from control and diabetic rats on day 17 of gestation. The data yield linear Scatchard plots on day 17 and the lines of best fit were found by linear regression analysis to be compatible with a single class of receptors with high-affinity binding site $\left(K_{\mathrm{D}}=5.4 \times 10^{-10}\right.$ and $6.0 \times 10^{-10}$, respectively). Receptor number in placental membranes from diabetic fetuses on day 17 is significantly $(P>0.05)$ reduced from a mean of $2.9 \times 10^{8}$ in the control to $1.8 \times 10^{8}$ in the diabetic. Data of placental membranes isolated from fetuses of controls on day 21 of gestation result in a curvilinear plot and is consistent with the model for two binding sites (Fig. 7). The plot can be resolved

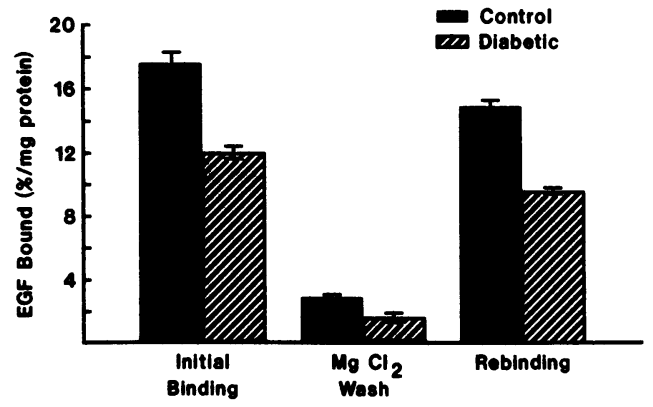

Figure 5. $\mathrm{MgCl}_{2}$ removal of ${ }^{125}$ I-EGF $(0.06 \mathrm{ng})$ bound to placental membranes isolated from control and diabetic rats on day 21 of gestation. Membranes were incubated with ${ }^{125}$ I-EGF $(30,000 \mathrm{dpm})$ in the presence and absence of excess unlabeled EGF ( $1 \mu \mathrm{g}$ per assay tube) pelleted, counted, and resuspended in $1 \mathrm{M} \mathrm{MgCl}_{2}$, and the binding assay was repeated. Data shown are the mean of six determinations \pm standard error per milligram of protein. 


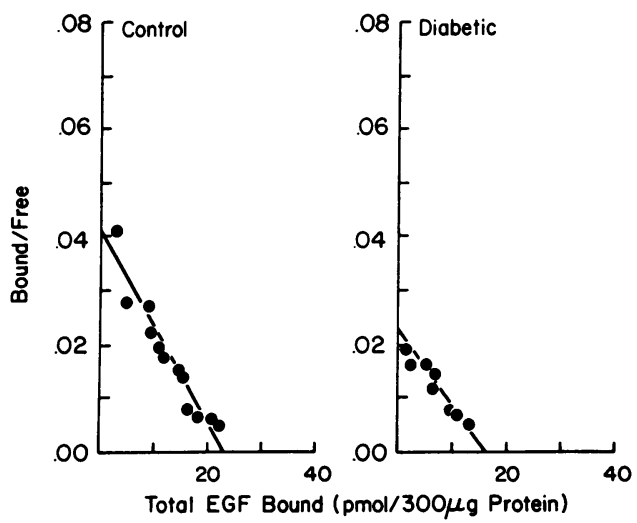

Figure 6. Representative Scatchard plot of binding data derived from placental membranes isolated from control and diabetic rats on day 17 of gestation. Plasma membranes ( $300 \mu \mathrm{g}$ of protein) were incubated for $90 \mathrm{~min}$ at $22^{\circ} \mathrm{C}$ with ${ }^{125}$ I-EGF $(30,000-35,000 \mathrm{dpm})$ in the presence of increasing concentrations (0-5.0 nM) of unlabeled EGF.

into two components representing a class of high-affinity sites with a $K_{\mathrm{D}}$ similar to that calculated from day 17 tissue $\left(K_{\mathrm{D}}=4.5\right.$ $\left.\times 10^{-10}\right)$ and a second class with a lower affinity $\left(K_{\mathrm{D}}=3.5\right.$ $\times\left(0^{-9}\right)$. In contrast, data from diabetic placentas result in linear

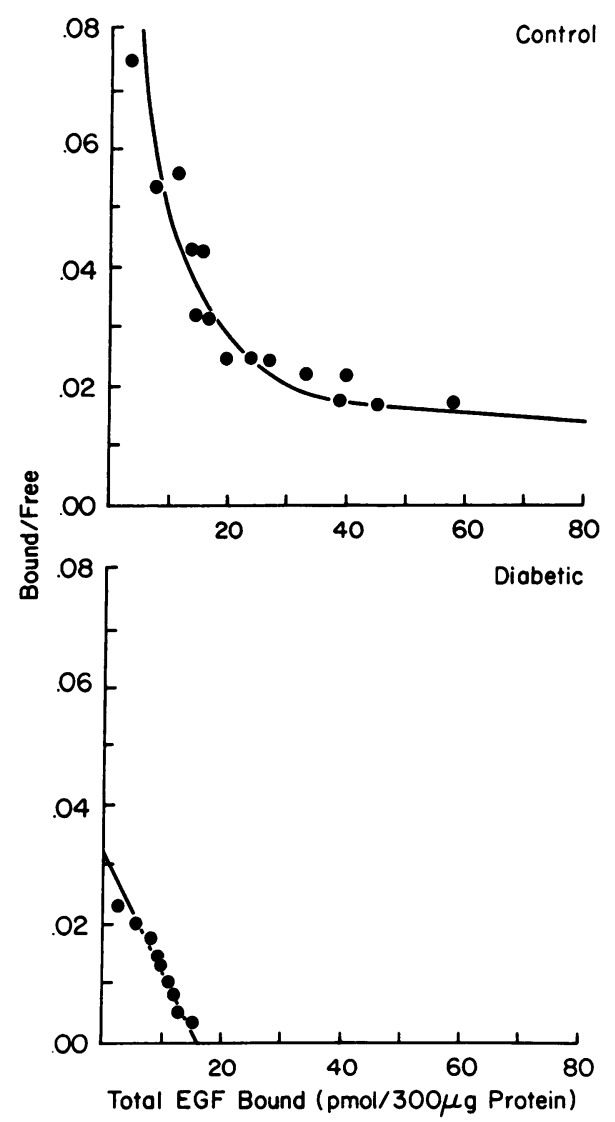

Figure 7. Representative Scatchard plot of binding data derived from placental membranes isolated from control and diabetic rats on day 21 of gestation. Plasma membranes ( $300 \mu \mathrm{g}$ of protein) were incubated for $90 \mathrm{~min}$ at $22^{\circ} \mathrm{C}$ with ${ }^{125} \mathrm{I}-\mathrm{EGF}(30,000-35,000 \mathrm{dpm})$ in the presence of increasing concentrations $(0-5.0 \mathrm{nM})$ of unlabeled EGF. Binding affinity is defined as in Fig. 4.
Table I. Levels of EGF

\begin{tabular}{llll}
\hline $\begin{array}{l}\text { Day of } \\
\text { gestation }\end{array}$ & Source of EGF & Control & Diabetic \\
\hline \multirow{3}{*}{17} & & $n g / m l$ & $n g / m l$ \\
& Serum & $*$ & $*$ \\
21 & Amniotic fluid & 0.4 & 0.4 \\
& Serum & 10.0 & 4.6 \\
& Amniotic fluid & 0.9 & 0.9
\end{tabular}

Radioreceptor assay of EGF: a displacement curve was constructed using human placental membranes, ${ }^{125}$ I-EGF, and varying amounts of unlabeled EGF. EGF activity present in the sample was estimated by the amount of ${ }^{125}$ I-EGF displaced.

*Fetuses removed on day 17 do not yield sufficient amounts of serum for the assay.

plots on day 21 , indicative of a single class of receptors with a high affinity binding site $\left(K_{\mathrm{D}}=4.5 \times 10^{-10}\right)$ and there is no indication of a second class of EGF-binding sites. Therefore, a greater number of binding sites are present in the membranes from control animals on day 21 when compared with those present in membranes from diabetic animals, primarily because of the development of the second class of binding sites with a lower affinity in membranes from control animals.

Results from radioreceptor assays for EGF are shown in Table I. Samples of amniotic fluid obtained on day 17 of gestation indicate $\sim 0.4 \mathrm{ng}$ of $\mathrm{EGF} / \mathrm{ml}$ of fluid in both the control and the diabetic. By day 21, the levels of EGF had increased in both groups to $\sim 0.9 \mathrm{ng} / \mathrm{ml}$. On day 21 the level of EGF in serum from fetuses of controls was $\sim 10.0 \mathrm{ng} / \mathrm{ml}$. Serum from fetuses of diabetic rats contained $4.6 \mathrm{ng} / \mathrm{ml}$, a figure that represents less than half the value found in controls. Fetuses removed on day 17 do not yield sufficient amounts of serum for the assay.

\section{Discussion}

Placentas from diabetic rats have been characterized by means of morphologic and biochemical indices as immature compared with those of control rats although the placentas continue to grow and have increased DNA content during the final stages of gestation. The immature state of placentas from diabetic animals is characterized by the presence of large numbers of glycogen-distended cells in the junctional zone (5). The interhemal membrane is significantly thicker in the diabetic placenta and large accumulations of lipid droplets are prominent. Previous studies have documented increased levels of glycogen in diabetic placentas and a delay in the appearance of active phosphorylase which likely regulates glycogenolysis (4). Placentas from diabetic animals at term (22 d) were histologically similar to 18-d control placentas. The amount of DNA in these placentas increases until the 19th day of gestation whereas maximum levels of DNA occur by days $16-17$ in placentas from control rats (4). It can be speculated that the decrease in EGF binding in the diabetic placenta is related to continued cell proliferation rather than maturation. A less mature placenta with thickened interhemal membranes may affect fetal growth by increasing the diffusion distance between maternal and fetal circulations (5) and may partially account for the limitation of fetal growth observed in this model.

In the present study we describe marked alteration in binding 
of EGF to plasma membranes of placentas in control and in streptozotocin-diabetic rats on days 17 and 21 of gestation. Adamson and Meek (9) have shown that EGF binds specifically to cells in vitro and stimulates the incorporation of tritiated thymidine into DNA of several tissues including the placenta. Adamson and Warshaw (8) demonstrated that EGF receptors on mouse placental membranes specifically bind trace amounts of ${ }^{125}$ I-EGF injected in vivo. Adamson and Meek (9) characterized EGF receptors during development of the fetal mouse. Their work suggests that this growth factor may stimulate cell proliferation early in gestation and maturation during the later stages of gestation.

We are aware of possible interaction of other groups of peptides (i.e., TGF- $\alpha$ ) with the EGF receptor which may influence binding of EGF to plasma membranes. TGF- $\alpha$ competes for the receptor but is antigenically unrelated to $\operatorname{EGF}(18,19)$. TGF- $\beta$ purified from human placenta interferes with receptor downregulation (20). To examine the possibility that one or more of these peptides is present in either the control placenta or the diabetic placenta and may contribute to the observed binding differences, the plasma membranes from control and diabetic rats were mixed equally (based on protein content). Competitive binding assays with mixed membranes gave intermediate values suggesting a similar level of receptor occupancy.

Because "endogenous" EGF in the tissue or serum may influence results from EGF binding data, $1 \mathrm{M} \mathrm{MgCl}_{2}$ was used to remove bound growth factor from the plasma membrane receptors. The results of this experiment more precisely define the binding capacity of the receptors. The membranes of placentas from each group were capable of rebinding $\sim 80 \%$ of the initial EGF bound. This indicates that EGF receptors found on both types of membranes were essentially unoccupied by ligand.

The importance of measuring blood and tissue levels of EGF is obvious to the full assessment of binding data. A radioreceptor assay was used inasmuch as a fully reliable radioimmunoassay for rat EGF is unavailable $(17,21)$. The levels of EGF in serum from day 21 diabetics are less than half the values measured in serum from control rats. These results indicate that the decreased binding in the diabetic is probably not a result of down-regulation of the EGF receptor. Results of competitive binding assays are consistent with the view that there is a developmental increase in binding sites for EGF in the placenta of control, near-term fetal rats. This increase is due primarily to the appearance of a second class of binding sites by day 21 . Placental membranes from day 17 diabetic rats show decreased EGF binding as compared with nondiabetic controls. Scatchard analysis indicates a single class of high-affinity receptors in both controls and diabetic rats $\left(K_{\mathrm{D}}=5.4 \times 10^{-10}\right.$ and $6.0 \times 10^{-10}$, respectively) and a significantly reduced $(30 \%)$ number of receptor sites in preparations from diabetic rats (Fig. 6). Placental membranes from day 21 diabetics show similar binding characteristics to those seen on day 17 (Fig. 7). By day 21, competitive EGF binding to membranes from controls result in a curvilinear plot suggestive of the appearance of a second class of receptors $\left(K_{\mathrm{D}}=3.5 \times 10^{-9}\right)$. The curvilinearity of this plot makes it difficult to precisely define receptor numbers for the two apparent sites. Data on day 21 of gestation however indicate a $30 \%$ reduction of specific binding to membranes from placentas of diabetic rats when compared with values for controls (Fig. 3). It is tempting to speculate that the receptor with higher affinity is present at an early stage of development when cell growth is the primary activity and as the levels of EGF rise in control rats near term, EGF induces the synthesis of its own receptor in a manner similar to that described by Earp et al. (22). In normal placenta, the appearance and occupancy of a second class of binding sites with a decreased affinity for EGF would be associated with a decrease in cell proliferation and an increase in maturation. Smith and Talamantes (23) recently reported a major increase in numbers of a loweraffinity binding site on mouse placental membranes toward the end of gestation. Their results differ from ours in that they observed curvilinear plots of EGF binding in mouse placental membranes for all gestational ages. This may relate to species differences. Lai and Guyda (10) have reported that ${ }^{125} \mathrm{I}-\mathrm{EGF}$ binding to membranes from human placental cell cultures also exhibited curvilinearity which they interpreted as receptor heterogenicity. This is consistent with our observations.

Excessive substrate supply as exists in the diabetic state may regulate EGF receptor number and affinity and result in continued cell division and growth at a time when the placenta normally undergoes hypertrophy and maturation. The precise mechanism by which the EGF receptor interacts with other hormones and available substrates to regulate developmental events in the placenta is unknown. Such differences as we report here in binding of EGF to placental membranes in the diabetic state may provide important clues concerning differential EGF influences on growth and maturation. In the placenta of a diabetic rat, continued cell proliferation and decreased binding of EGF may be due to masking of the EGF receptor in the membrane, alterations in receptor cycling, or alterations in the synthesis, processing, or insertion into the plasma membrane of the new receptor. These possibilities are currently being investigated.

\section{Acknowledgments}

The authors gratefully acknowledge the editorial assistance of Silver Lee. This work was supported by research grant HL-30119 from the National Institutes of Health.

\section{References}

1. Neufeld, N. D., L. M. Corbo, and S. A. Kaplan. 1981. Plasma membrane insulin receptors in fetal rabbit lung. Pediatr. Res. 15:10581062.

2. Neufeld, N. D., S. A. Kaplan, B. M. Lippe, and M. Scott. 1978. Increased monocyte receptor binding of $\left[{ }^{125} \mathrm{I}\right]$-insulin in infants of gestational diabetic mothers. Clin. Endocrinol. Metab. 47:590-595.

3. Robert, M. F., R. K. Neff, J. P. Hubbell, H. W. Taeusch, and M. E. Avery. 1976. Association between maternal diabetes and the respiratory-distress syndrome in the newborn. N. Eng. J. Med. 294:357360.

4. Gewolb, I. H., C. Barrett, and J. B. Warshaw. 1983. Placental growth and glycogen metabolism in streptozotocin diabetic rats. Pediatr. Res. 17:587-591.

5. Gewolb, I. H., W. Meridian, J. B. Warshaw, and A. C. Enders. 1986. Fine structural abnormalities of the placenta in the diabetic rat. Diabetes. 35:1254-1261.

6. Ullrich, A., L. Coussens, J. S. Hayflick, T. J. Dull, A. Gray, A. W. Tam, J. Lee, Y. Yarden, T. A. Libermann, J. Schlessinger, J. Downward, E. L. V. Mayes, N. Whittle, M. D. Waterfield, and P. H. Seeburg. 1984. Human epidermal growth factor receptor cDNA sequence and aberrant expression of the amplified gene in A431 epidermoid carcinoma cells. Nature (Lond.). 309:418-425.

7. Cohen, S., H. Ushiro, C. Stoscheck, and M. Chinkers. 1982. A native 170,000 epidermal growth factor receptor-kinase complex from shed plasma membrane vesicles. J. Biol. Chem. 257:1523-1531. 
8. Adamson, E. D., and J. B. Warshaw. 1982. Down-regulation of epidermal growth factor receptors in mouse embryos. Dev. Biol. 90:430434.

9. Adamson, E. D., and J. Meek. 1984. The ontogeny of epidermal growth factor receptors during mouse development. Dev. Biol. 103:6270.

10. Lai, W. H., and H. J. Guyda. 1984. Characterization and regulation of epidermal growth factor receptors in human placental cell cultures. Clin. Endocrinol. Metab. 58:344-352.

11, Morishige, W. K., C. Uetake, F. C. Greenwood, and J. Akaka. 1977. Pulmonary insulin responsivity: in vivo effects of insulin on the diabetic rat lung and specific insulin binding to lung receptors in normal rats. Endocrinology. 100:1710-1722.

12. Lowry, O. H., N. J. Rosebrough, A. L. Farr, and R. J. Randall. 1951. Protein measurement with the folin phenol reagent. J. Biol. Chem. 193:265-275.

13. Arkesteijn, C. L. M. 1976. A kinetic method for serum 5'-nucleotidase using stabilized glutamate dehydrogenase. Clin. Chem. Clin. Biochem. 14:155-158.

14. Scatchard, G. 1949. The attractions of proteins for small molecules and ions. Ann. N.Y. Acad. Sci. 51:660-672.

15. Munson, P. J., and D. Rodbard. 1980. LIGAND: A versatile computerized approach for characterization of ligand-binding systems. Anal. Biochem. 107:220-239.

16. Kelly, P. A., G. LeBlanc, and J. Djiane. 1979. Estimation of total prolactin-binding sites after in vitro desaturation. Endocrinology. 104: 1631-1638.

17. Hock, R. A., and M. D. Hollenburg. 1980. Characterization of the receptor for epidermal growth factor-urogastrone in human placenta membranes. J. Biol. Chem. 255:10731-10736.

18. Twardzik, D. R., E. S. Kimball, S. A. Sherwin, J. E. Ranchalis, and G. J. Todaro. 1985. Comparison of growth factors functionally related to epidermal growth factor in the urine of normal and human tumorbearing athymic mice. Cancer Res. 45:1934-1939.

19. Frolik, C. A., L. L. Dart, C. A. Meyers, D. M. Smith, and M. B. Sporn. 1983. Purification and initial characterization of a type $\beta$ transforming growth factor from human placenta. Proc. Natl. Acad. Sci. USA. 80:3676-3680.

20. Assoian, R. K., C. A. Frolik, A. B. Roberts, D. M. Miller, and M. B. Sporn. 1984. Transforming growth factor $-\beta$ controls receptor levels for epidermal growth factor in NRK fibroblasts. Cell. 36:35-41.

21. Ladda, R. L., L. P. Bullock, T. Gianopoulos, and L. McCormick, 1979. Radioreceptor assay for epidermal growth factor. Anal. Biochem. 93:286-294.

22. Earp, H. S., K. S. Austin, J. Blaisdell, R. A. Rubin, K. G. Nelson, L. W. Lee, and J. W. Grisham. 1986. Epidermal growth factor (EGF) stimulates EGF receptor synthesis. J. Biol. Chem. 261:4777-4780.

23. Smith, W. C., and F. Talamantes. 1986. Characterization of the mouse placental epidermal growth factor receptor: changes in receptor number with day of gestation. Placenta. 7:511-522. 